\title{
Evaluation of serum syndecan-1 level in patients of multiple myeloma
}

\author{
Kanika Yadav ${ }^{1}$, Chandra $\mathrm{H}^{2}$, Chandra $\mathrm{S}^{1 *}$, Negi $\mathrm{G}^{3}$ and Verma $\mathrm{SK}^{4}$ \\ ${ }^{1}$ Department of Pathology, Himalayan Institute of Medical Sciences, Dehradun, Uttarakhand, India \\ ${ }^{2}$ Department of Pathology, All India Institute of Medical Sciences, Rishikesh, India \\ ${ }^{3}$ Department of Transfusion Medicine, All India Institute of Medical Sciences, Rishikesh, India \\ ${ }^{4}$ Department of Medicine, Himalayan Institute of Medical Sciences, Dehradun, Uttarakhand, India
}

\begin{abstract}
Introduction: The homing of tumor cells to bone marrow in multiple myeloma is mediated by adhesion molecules syndecan-1 which is being investigated in pathogenesis and prognosis of myeloma. The present study was conducted to analyze serum syndecan-1 level at the time of initial diagnosis and after therapeutic response along with its correlation with staging and mortality in patients of myeloma of this north Himalayan region of India.

Material and methods: The study included thirty cases of multiple myeloma and serum syndecan-1 level was analyzed and correlated with beta 2 microglobulin and other diagnostic parameters of myeloma both at the time of diagnosis and after treatment. Serum syndecan-1 level was also correlated with the stage and mortality of patients.

Results: The mean level of serum syndecan-1 in cases was $239.22 \mathrm{ng} / \mathrm{ml}$ which was statistical significantly higher (p < 0.001$)$ than controls (42.23 ng/ml). There was significant decrease in serum syndecan-1 level and beta 2 microglobulin after treatment (serum syndecan-1 level $169.29 \mathrm{ng} / \mathrm{ml}$ and beta $2 \mathrm{microglobulin} 5.58 \mathrm{ng} / \mathrm{ml}$ ). The mean serum syndecan-1 level was higher in patients who died $(270.52 \mathrm{ng} / \mathrm{ml})$ in comparison to the patients who were alive ( $227.84 \mathrm{ng} / \mathrm{ml})$. Stage I observed mean serum syndecan-1 level of $140.66 \mathrm{ng} / \mathrm{ml}$, stage II $208.66 \mathrm{ng} / \mathrm{ml}$ and stage III $270.93 \mathrm{ng} / \mathrm{ml}$ and this association was found to be statistically significant ( $\mathrm{p}=0.05$ ).

Conclusion: Serum syndecan-1 level was higher at initial diagnosis and significantly decreased after treatment with correlation of serum beta 2 microglobulin and creatinine suggesting its role in pathogenesis and progression of multiple myeloma. The increase of serum syndecan-1 level with stage of disease and higher levels in patients who succumbed to their illness also suggests its prognostic implication. Further studies with extended follow up in different ethnical populations may be done to evaluate serum syndecan-1 and determine its therapeutic utility in myeloma.
\end{abstract}

\section{Introduction}

Multiple myeloma (MM) is a plasma cell dyscrasia with the expression of abnormal monoclonal $M$ protein due to switch mutations in Ig gene [1]. The malignant plasma cells adhere to and interact with extracellular matrix and stromal cells in bone marrow leading to their survival by inhibiting apoptosis and protecting them from therapy induced cell death. This homing of tumor cells to bone marrow is mediated by different adhesion molecules including CD 44, leucocyte function associated antigen 1 (LFA-1), neuronal adhesion molecule (NCAM) and syndecan-1 (CD 138). Syndecan-1 is cell surface transmembrane heparan sulphate proteoglycan expressed by both normal and myeloma plasma cells [2]. Although serum syndecan levels have been said to be associated with high percentage of plasma cells in the marrow but its role in pathogenesis and prognostic value is still being investigated in MM and monoclonal gammopathy of undetermined significance (MGUS) [3,4]. In addition, it has also been suggested that difference in level of syndecan 1 in MM may also be related to racial differences [5].

The present study was therefore conducted to analyze serum syndecan level at the time of initial diagnosis of MM and in follow up after therapeutic response. It was also intended to compare this level with beta 2 microglobulin and other diagnostic parameters of MM. The study would be therefore helpful in evaluating the role of serum syndecan-1 in pathogenesis and prognosis of MM.

\section{Material and methods}

The study was conducted in the Hematology section of the department of Pathology over period of one year from October 2014 till September 2015. The study included thirty newly diagnosed cases of multiple myeloma and thirty healthy controls after written informed consent. Relevant clinical and laboratory details were noted, and all the cases were followed up for at least one year. The peripheral blood sample was obtained twice at the time of diagnosis and in follow up after the initiation of the therapy. The serum was separated and stored at -80 degrees centigrade and serum syndecan-1 level (Diaclone Research, France) and beta 2 microglobulin level (Calbiotech, USA) was measured by enzyme linked immunoabsorbent assay (ELISA). The bone marrow plasma cell percentage, serum $M$ protein, hemoglobin, serum albumin, globulin, calcium, creatinine, serum IgG, IgA, Bence

Correspondence to: Smita Chandra, Department of Pathology, Himalayan Institute of Medical Sciences, Dehradun, Uttarakhand, India, Tel: +91941171855; E-mail: smita_harish@yahoo.com

Key words: Multiple myeloma, serum syndecan-1, pre-treatment level, posttreatment level

Received: January 26, 2018; Accepted: February 20, 2018; Published: February 23, 2018 
Jones protein and $\mathrm{X}$ ray skull were noted for every case. The staging of the patients was done using the Durie Salmon staging system [6]. The statistical analysis was done using statistical package for social sciences (SPSS) version 22 software. Student $t$ test was used to compare the cases and controls along with pre and post treatment groups. Pearson correlation coefficient was used to study the correlation of the different parameters. Test of variance was used for association between serum syndecan- 1 and the stage of the disease. $\mathrm{p}$ value less than 0.05 was considered statistically significant.

\section{Results}

The study which included thirty patients of MM showed male female ratio of 1.14:1 with median age of 60 years and range of 3082 years. The mean level of serum syndecan- 1 in cases at the time of diagnosis was $239.22 \mathrm{ng} / \mathrm{ml}$ (median level $307.63 \mathrm{ng} / \mathrm{ml}$ ) which was statistical significantly higher $(\mathrm{p}<0.001)$ than controls which showed mean level of $42.23 \mathrm{ng} / \mathrm{ml}$. Table 1 shows the various clinical and laboratory parameters at the time of diagnosis of MM cases. Table 2 shows that there was significant decrease in serum syndecan- 1 level and beta 2 microglobulin after treatment in follow up. Figure 1 shows that serum syndecan- 1 and beta 2 microglobulin level showed statistical significant correlation both pre and post treatment. Although serum syndecan- 1 level positively correlated with serum creatinine $(r=0.35$, $\mathrm{p}=0.04$ ) but it showed no correlation with serum calcium level in the study. During the follow up, eight patients died with survivorship of $73.3 \%$. The mean serum syndecan-1 level was higher in patients who died $(270.52 \mathrm{ng} / \mathrm{ml})$ in comparison to the patients who were alive $(227.84 \mathrm{ng} / \mathrm{ml})$ but this difference was not statistical significant $(\mathrm{p}=0.345)$. The serum syndecan-1 level also showed increase in levels with the stage of the disease. Stage I observed mean serum syndecan-1 level of $140.66 \mathrm{ng} / \mathrm{ml}$, stage II $208.66 \mathrm{ng} / \mathrm{ml}$ and stage III $270.93 \mathrm{ng} / \mathrm{ml}$ and this association was found to be statistically significant $(\mathrm{p}=0.05)$.

\section{Discussion}

Multiple myeloma, a plasma cell malignancy involves different cytokines including angiogenic and cytoadhesive molecules for its

Table 1. Clinical and laboratory characteristics in cases of MM at diagnosis

\begin{tabular}{|c|c|}
\hline Characteristics & Mean - SD \\
\hline Serum Calcium $(\mathrm{mg} / \mathrm{dl})$ & $9.64+2.27$ \\
\hline Serum Creatinine $(\mathrm{mg} / \mathrm{dl})$ & $3.78+0.21$ \\
\hline Serum Total protein $(\mathrm{g} / \mathrm{dl})$ & $9.08+2.10$ \\
\hline Serum Albumin $(\mathrm{g} / \mathrm{dl})$ & $2.50+0.74$ \\
\hline Serum M-protein $(\mathrm{g} / \mathrm{dl})$ & $2.60+1.67$ \\
\hline M Ig type (\% of patients) & 61 \\
\hline IgG & 27 \\
IgA & 1 \\
Biclonal & 11 \\
\hline Bence Jones protein & $7.95+1.87$ \\
\hline Hemoglobin (g/dl) & 51 \\
\hline Lytic bony lesions $(\%$ of patients) & 10 \\
\hline Durie Salmon stage (\% of patients) & 30 \\
Stage I & 60 \\
\hline Stage II & \\
Stage III & \\
\hline
\end{tabular}

Table 2. Serum syndecan- 1 and beta 2 microglobulin pre and post treatment in cases of MM

\begin{tabular}{|c|c|c|c|}
\hline Characteristic & $\begin{array}{c}\text { Pre-treatment } \\
\text { Mean +SD }(\mathrm{ng} / \mathrm{ml})\end{array}$ & $\begin{array}{c}\text { Post-treatment } \\
\text { Mean }+\mathrm{SD}(\mathrm{ng} / \mathrm{ml})\end{array}$ & P value \\
\hline Serum syndecan-1 & $239.22+107.54$ & $169.29+136.44$ & $\mathrm{P}=0.001$ \\
\hline $\begin{array}{c}\text { Serum Beta 2 } \\
\text { microglobulin }\end{array}$ & $8+4.57$ & $5.58+4.09$ & $\mathrm{P}=0.020$ \\
\hline
\end{tabular}
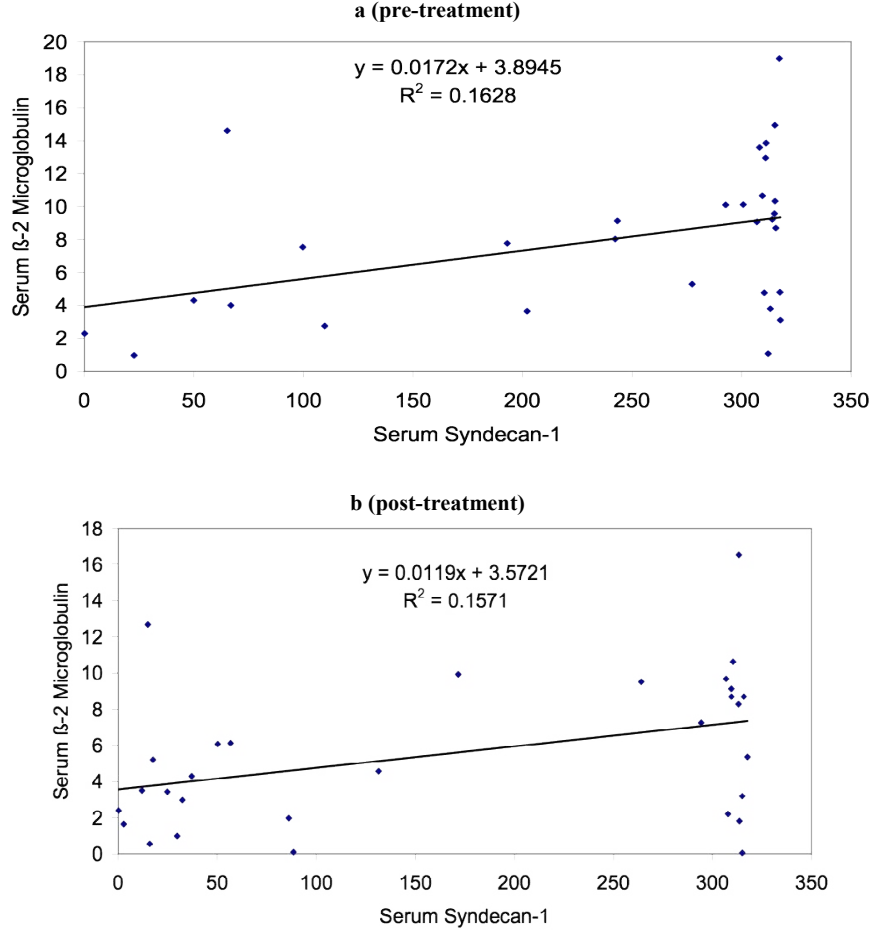

Figure 1. Correlation of serum syndecan-1 and beta 2 microglobulin (a) pre- treatment and (b) post-treatment

pathogenesis. Syndecan-1 is expressed on mature plasma cells and is shed in the serum as soluble syndecan-1. However, Cigliana et al have reported that this shedding varies according to the free light chains released by myeloma cells [7]. The soluble syndecan-1 is considered to play an important role in the growth of myeloma cells and its levels have been studied in different clinical settings in plasma cell dyscrasia $[5,8]$. The present study observed a significantly higher level of serum syndecan-1 in MM (239.22 ng/ml) in comparison to controls (42.23 ng/ $\mathrm{ml})$. Other studies have also observed high levels of serum syndecan-1 in MM but present study showed more level in comparison to them $[3,9]$. However, Lovell et al observed significantly higher level of serum syndecan-1 in their study $(336 \mathrm{ng} / \mathrm{ml})$ in comparison to the present study. This difference in levels of serum syndecan-1 in MM may be attributed to the racial differences or may be related to stage of disease [5]. The present study also observed $60 \%$ of the patients in stage III and with higher serum syndecan levels in comparison to stage I and II suggesting that increased levels may be related to higher stage of the disease. It was also observed that serum syndecan-1 level correlated with beta 2 microglobulin both pre and post treatment and showed significant decrease after treatment. This suggests that syndecan-1 may play an important role in progression of the disease. The level of serum syndecan-1 also positively correlated with serum creatinine and thus suggesting its association with renal failure in MM. Similar findings have been observed by other studies which concluded that serum syndecan-1 level is an indicator of severity of renal failure in MM $[9,10]$. Another important finding that was observed in the present study was that serum syndecan -1 level was higher in patients who died in comparison to alive and thus indicating that higher syndecan level is associated with poor prognosis in cases of MM. Kim et al have also observed that the rate of therapeutic response in patients with low baseline levels of soluble syndecan-1 was higher than in the patients with high baseline levels [5]. Recently, it has been suggested that shed syndecan-1 from the surface of MM cells translocate to the nucleus and 
binds to the histone acetyltransferase enzyme p300 diminishing the activity of histone acetyltransferase and histone acetylation revealing novel function of tumor host interaction [11]. Studies have suggested that syndecan-1 may thus be useful for target of novel therapeutic strategy in MM [12,13].

However, an important limitation of the present study was that it comprised of limited number of cases and without extended follow up. The authors therefore suggest that a larger study with more number of cases and extended follow up may be done to determine the diagnostic and prognostic utility of serum syndecan-1 which may be further evaluated for therapeutic strategy in MM.

\section{Conclusion}

Serum syndecan-1 level is higher in MM at the time of initial diagnosis and significantly decreased after treatment with correlation of serum beta 2 microglobulin and creatinine. This suggests that serum syndecan-1 may play an important role in pathogenesis and progression of MM. The increase of serum syndecan-1 level with the stage of the disease and higher levels in the patients who succumbed to their illness also suggests its prognostic implication in MM. The authors suggest further larger studies with extended follow up in different ethnical populations to determine the diagnostic and prognostic utility of serum syndecan-1 which may be further evaluated for therapeutic strategy in MM.

\section{Financial support}

\section{None}

\section{Conflicts of interest}

\section{None}

\section{References}

1. Ghobrial IM, Laubach J, Richardson PG (2010) Plasma cell dyscrasias. In American Society of Hematology self-assessment program. 4th Edition. Published by American Society of Hematology. Washington. 581-604.
2. Costes V, Magen V, Legouffe E, Durand L, Baldet P, et al. (1999) The Mi15 monoclonal antibody (serum syndecan-1) is a reliable marker for quantifying plasma cells in paraffin embedded bone marrow biopsy specimens. Hum Pathol 30: 1405-1411. [Crossref]

3. Seidel C, Sundan A, Hjorth M, Turesson I, Dahl IM, et al. (2000) Serum syndecan-1: a new independent prognostic marker in multiple myeloma. Blood 95: 388-392. [Crossref]

4. Lovell R, Dunn JA, Begum G, Barth NJ, Plant T, et al. (2005) Soluble syndecan-1 level at diagnosis is an independent prognostic factor in multiple myeloma and the extent of fall from diagnosis to plateau predicts overall survival. Br J Haematol 130: 542-548. [Crossref]

5. Kim JM, Lee JA, Cho IS, Ihm CH (2010) Soluble syndecan-1 at diagnosis and during follow up of multiple myeloma: a single institution study. Korean J Hematol 45: 115119. [Crossref]

6. Durie BG, Salmon SE (1975) A clinical staging system for multiple myeloma: correlation of measured myeloma cell mass with presenting clinical features, response to treatment and survival. Cancer 36: 842-854. [Crossref]

7. Cigliana G, Torti E, Gulli F, Santis DeE, Abate Dell MT, et al. (2015) Relationship between circulating syndecan-1 levels (CD $138 \mathrm{~s}$ ) and serum free light chains in monoclonal gammopathies. J Exp Clin Cancer Res 34: 37. [Crossref]

8. Yang Y, Yaccoby S, Liu W, Langford JK, Pumphrey CY, et al. (2002) Soluble syndecan-1 promotes growth of myeloma tumors in vivo. Blood 100: 610-617. [Crossref]

9. Kumar S, Blood E, Oken MM, Greipp PR (2004) Prognostic value of syndecan-1 in multiple myeloma and its relationship with other prognostic factors. Blood 104: 2402.

10. Jansoi J, Sebestyen A, Mikala G, Nemeth J, Kiss Z, et al. (2004) Soluble syndecan-1 levels in different plasma cell dyscrasias and in different stages of multiple myeloma. Haematologica 89: 370-371. [Crossref]

11. Stewart MD, Ramani VC, Sanderson RD (2015) Shed syndecan-1 translocates to the nucleus of cells delivering growth factors and inhibiting histone acetylation: a novel mechanism of tumor-host cross talk. J Biol Chem 290: 941-949. [Crossref]

12. Yang Y, MacLeod V, Dai Y, Khotskaya-Sample Y, Shriver Z, et al. (2007) The syndecan-1 heparan sulphate proteoglycan is a viable target for myeloma therapy. Blood 110: 2041-2048. [Crossref]

13. Ramana VC, Sanderson RD (2014) Chemotherapy stimulates syndecan-1 shedding: a potentially negative effect of treatment that may promote tumor relapse. Matrix Biol 35: 215-22. [Crossref] 